\section{Intra-organizational conflict: Origin and cost}

\section{David Zetland}

$\mathrm{T}$ his article tells the story of an organization-the Metropolitan Water District of Southern California (MET, for short) — that suffers from internal conflict. The story is important not just because MET supplies about half of the urban water in southern California, but because it highlights how conflict can arise and persist inside an organization. The key to understanding this story lies with the role of institutions (rules and norms), and how institutions may fail to evolve with circumstances. As differences between potential, appropriate and actual, inappropriate actions accumulate, outdated institutions impose greater costs with time. These costs cannot mount indefinitely: Eventually they grow so large that the organization is reformed by internal forces (management recognizes a need to change) or external forces (political intervention or competition forces change). In the worst case, the water management organization collapses, sometimes taking an entire society with it. ${ }^{1}$

This story of conflict over water within an organization is a logical extension, and complement, to studies of conflict over water among organizations (governments) that were highlighted in a 2007 symposium issue in volume 2(2) of this journal. Among the contributors to that issue, Frederic Pryor offers useful parallels: He examines different global regions for their potential for violent conflict and concludes "that in the coming decades the probability for interstate armed conflict over water is low." He reasons that conflict is costly, victory is hard to maintain in the long run, and improvements in water management are easier to accomplish than going to war. Even as its member agencies fight over water policies and water allocation, these ideas apply to MET because they explain why it has not broken up (too costly) and how MET can end conflict (improvements in water management). ${ }^{2}$

Before addressing why MET suffers from conflict, it needs to be clarified that as used here conflict does not refer to day-to-day process of "groping for success," characterized by battles over personnel, budgets, or products lines. Those costs are part of a process that has a positive expected value because they push the organization in the right direction, toward higher profits. Instead, in this article conflict refers to negative expected value such as zero- or negative-sum fights over access to MET's water or cross-subsidies to projects that do not pass cost-benefit criteria (except for those member agencies that benefit from a project subsidized by others). These conflicts can persist because MET is a government agency with a monopoly on water distribution, faces weak outside pressure for change, and distributes the costs of conflict and inefficiency to member agencies who have little say over operations and generally no idea of MET's (in)efficiency. (This example of conflict may also apply to water distribution organizations that have an asymmetric distribution of costs and benefits among customers.)
This article examines how conflict was built into MET's foundation documents but also how a conflict-alleviation mechanism included in those documents was ignored. This made it easy for those who wanted to use the mechanism as well as for those who preferred to keep ignoring it to claim the mantle of righteousness in the debate over how to respond to inefficiency. From this "original sin" came additional conflict, with heavy costs. Conflict persisted for three main reasons: (1) the political decisionmaking mechanism within the organization, (2) that through cost shifting outsiders bore (and bear) the cost of conflict, and (3) the lack of exit options due to the MET's monopoly status. The solution to MET's internal conflict requires that leaders adopt a new set of tools that reduce their control over the way MET allocates water and money. Market and price tools are familiar to economists but not often used by the engineers, bureaucrats, and politicians who control MET's policies and operations. Because these managers bear the cost of change without obvious benefit to themselves, and because water customers bear the cost of inefficiency without power to change MET, inertia and inefficiency persist.

\section{Some background on MET}

California's legislature created the Metropolitan Water District of Southern California (MET) in 1928. MET's founding members were Los Angeles and twelve other cities. Although founded for the purpose of importing water from the Colorado river to southern California, its member agencies wanted these imports for different reasons: The twelve cities wanted water imports so that they could grow without relying on Los Angeles and its aqueduct that brought water from the Owens valley. Los Angeles, in contrast, did not so much want water as cheap electricity from hydropower. Figure 1 -appended to this article-shows MET's current service area and water sources and the (now) 26 member agencies.

The Los Angeles aqueduct had given the Los Angeles Department of Water and Power (LADWP) a taste for cheap hydropower and LADWP used it to reduce its reliance on Southern California Edison, an investor-owned utility. Wanting more electric power, LADWP envisioned a dam on the Colorado as an obvious and potent source. The Hoover dam—an expensive idea in a federal jurisdiction—did not yet 
exist. In its original design, the Hoover was to deliver hydropower to southern California and neighboring areas but the idea was foiled at the federal level by a coalition of fiscal conservatives who did not fancy to pay for the largest dam ever designed and political conservatives who did not want more socialized power. So the 1920 proposal by LADWP's Ezra Scattergood to build a power-only dam was, at first, defeated. ${ }^{3}$ But in 1923, one year after proclaiming that Los Angeles had four times its water requirements, LADWP's William Mulholland proposed that a Colorado River Aqueduct (CRA) bring water from the Colorado to "parched" southern California. As the CRA would need to travel over mountains - requiring pumps and power-it was convenient to recall that the Hoover dam could both generate electricity for the CRA and leave enough for LADWP to get its cheap power. The constellation was right, and the dam built. As of 2010, MET and LADWP buy, respectively, 28.5 and 15.4 percent of Hoover's electricity, at prices that are significantly lower than market rates.

Thus MET was birthed for reasons of water and power, and its main purpose was to build the CRA. An engineering masterpiece, but an economic disaster, MET planned to recover CRA costs in the price of water at several times the cost of local groundwater. Since MET's non-Los Angeles member agencies balked at paying such a high price, property taxes across all member agencies were used to cover MET's costs and subsidize water prices. Lower prices helped MET sell more water, but the subsidies created a different problem in the form of Preferential Rights (PRs), giving rights holders preferential access to MET water in times of shortage. PRs were included in MET's original charter as compensation to member agencies that covered MET's costs. By 1954, Los Angeles, with nearly 70 percent of MET's tax base, had paid 61 percent of MET's costs in exchange for only 8 percent of its water. ${ }^{4} 1954$ was also the first year in which MET's sales revenue covered its operating costs. Since demand was then only equal to one-quarter of CRA capacity, PRs were not worth anything. PRs continued to accrue and by 2006, LADWP's share of PRs were equivalent to 208 percent of its average 1979 to 2005 water deliveries, which means that LADWP could theoretically claim double its average MET delivery in the event of a drought. (We will see later that this claim stayed theoretical.)

Returning to the 1940s: With the CRA and the Hoover dam in operation, MET was looking for new sources of demand for its abundant water and for sales revenue to cover its costs. Between 1946 and 1955, MET's Board of Directors voted to "annex" new member agencies with lots of land but few people, increasing its service area by 200 percent and population by 75 percent. ${ }^{5}$ Unlike MET's thirteen founding cities that sold water directly to retail consumers, the new member agencies were regional wholesale organizations, Municipal Water Districts (MWDs), that sold water to cities. In turn, MWD's were attracted by MET's relatively cheap supplies of surface water and its guarantee of water for future growth, as proclaimed in MET's 1952 Laguna Declaration:
"The [Metropolitan Water] District is prepared, with its existing governmental powers and its present and projected distribution facilities, to provide its service area with adequate supplies of water to meet expanding and increasing needs in the years ahead. When and as additional water resources are required to meet increasing needs for domestic, industrial and municipal water, the District will be prepared to deliver such supplies.

Taxpayers and water users residing within the District already have obligated themselves for the construction of an aqueduct supply and distribution system. This system has been designed and constructed in a manner that permits orderly and economic extensions and enlargements to deliver the District's full share of Colorado River water and State Project water as well as water from other sources as required in the years ahead. Establishment of overlapping and paralleling governmental authorities and water distribution facilities to service Southern California areas would place a wasteful and unnecessary financial burden upon all of the people of California, and particularly the residents of Southern California.”

MET worked to increase demand for its then-abundant supply, using subsidies to lower the price of water to existing and new member agencies. These subsidies were only phased out slowly. (Revenue from operations surpassed revenue from property taxes in 1973.) Although it could be predicted that demand would overtake supply, MET's Laguna Declaration was intended to alleviate this very concern. In fact, MET issued the Declaration in 1952 as a first step in gaining additional water from California's vast and expensive State Water Project (SWP), and in 1960, MET signed contracts committing itself to buy about half of SWP's water, more than doubling its supply. MET seemed well on its way to a future of prosperity in which all member agencies would receive as much water as they needed at reasonable prices. That vision turned out to be mistaken, and MET's failure to reform its institutions turned increasing supply and demand imbalances into shortages and conflict.

\section{The origins of conflict}

California's legislature established MET as a cooperative of member agencies that would work together to build the CRA. Member votes on the Board of Directors were in proportion to their share of assessed value of real estate within MET's service area. At its foundation, MET's board was dominated by Los Angeles, which had 80 percent of assessed value but a voting share that was capped at 50 percent. By all accounts, members were in broad agreement in MET's early years: First, they agreed to build the CRA, for water and power; second, they agreed that Los Angeles would subsidize debt and operating expenses to make water prices attractive; and third, they agreed to expand, to generate more demand - and revenue. Agreement started to unravel in the 1960s and 1970s, when MET's supplies started to look less reliable and demand grew by leaps and bounds. MET's member agencies then divided into two main groups: 
(C) www.epsjournal.org.uk - Vol. 6, No. 1 (2011)

Those who favored paying more for reliable water and those who favored paying less for less reliability of water supplies and deliveries.

Efficiency in a cooperative

In economic theory, cooperatives are more efficient than organizations with outside ownership (profit-maximizing firms) if and only if its members share a single goal or the same ordering of goals, i.e., their preferences are reasonably homogenous. Thus, MET will be inefficient if its member agencies have heterogeneous preferences over its activities, for instance, reliability versus low prices. Inefficiency will manifest itself in arguments over policy design or the implementation of policy that reflects the preferences of the politically dominant group.

Given that cooperative members will have preferences over activities, there will also be a distribution of members' preferences. The skewness of this distribution (the degree to which the mean diverges from the median) indicates the propensity for members to disagree or enact misaligned policies that reduce cooperative efficiency relative to that of a profit-oriented firm. Skewness manifests itself in policymaking. Because cooperatives (and MET) generally use a median voter method of making decisions, while the mean may reflect willingness to pay, divergence of these two measures indicates the divergence of political and economic power. The greater this divergence, the greater the potential redistribution of gains and losses from cooperative policies and thus the greater the conflict prior to making these policies.

Heterogeneity has been present ever since MET's foundation. Table 1, also appended, shows how member agencies vary widely in area, population, water use, and local water supply. But heterogeneity was not relevant until the 1970s, when problems with scarcity began to emerge. Until then, heterogeneity was "hidden.” Researchers say that reasonably homogenous preferences are necessary and sufficient for cooperative efficiency. ${ }^{6}$ They assume that cooperative members are self-interested and that the consumer/producer cooperative allocates a scarce good. If we relax the assumptions, homogenous preferences are still sufficient but no longer necessary, and two alternative sufficient conditions for efficiency emerge. First, members of the cooperative may have social preferences such that they consider the welfare of others in addition to their own. When members with social preferences decide cooperative policies, they put more weight on group welfare and offset all or part of their underlying differences. The resulting policies maximize group surplus because the cooperative produces more public goods and creates more benefits than the sum of individual contributions necessary to create them. In MET's early years, the Board of Directors acted as if it wanted to maximize surplus in the MET area. Although that era has ended, it is possible that today's water managers have social preferences and cooperate to maximize group surplus. But they do not: MET's executives and member agency managers who took part in experiments revealed self-interested preferences in roughly the same proportion as control participants from the general population. ${ }^{7}$
Second, the cooperative may produce a good in such abundance that consumption by one member does not reduce the amount available to another member. Without rivalry over consumption, the cooperative need not ration the good. Because all members can consume as much as they want, according to their various preferences, MET is efficient. Until the 1960s, MET had abundant water, and LADWP paid most costs, so MET was efficient. MET could treat water as a club good, meaning that MET's allocation policies would be efficient because member agencies could get as much as they wanted. Members did not have to decide if MET should supply large quantities of expensive water or smaller quantities of cheaper water.

As from the 1960s, MET's abundant and cheap water did become scarce and expensive. Rivalry replaced nonrivalry inside MET, even as membership guaranteed access. MET's water turned from a club good into a common pool good: All members had access to it; but use depleted supplies for others. Rivalry over supply (water used by one member left less of other members) and costs (expenses created by one member were borne by other members) required that MET change its institutions for managing water and cost. But because of members' heterogeneous preferences, efficiency was lost in the debate over change and the use of old and new policies that served some members at the expense of others.

Without social preferences or abundance, the analysis collapses to that of Hart and Moore (see references), and the question returns to homogeneity of preferences: Are member agencies' preferences homogeneous enough to deliver efficiency? If one assumes that preferences follow from characteristics (for instance, that dependency on MET for water leads to a preference for policies that increase reliability of MET supplies) and shows that member agencies do not have homogenous characteristics, then one can conclude that they do not have homogenous preferences either.

\section{Dependency}

Although water managers' most important concern is reliability in water supply, ${ }^{8}$ the relative importance of reliability over low prices varies, reliability being more important for members that are more dependent on MET. To quantify and compare heterogeneity, an index was created to measure MET members' twofold dependency: from a lack of alternatives to MET (via MET's share of a member's total water supply) and from being a big customer (via the member's share in MET's total sales). ${ }^{9}$ The first - dependency on MET as a big supplier — is intuitive; the second - big customer dependency - may not be so obvious. Member agencies want to avoid this second type of dependency because it is difficult to find alternative water suppliers in MET's large service area. For example, suppose that the CRA is shut down for some reason. Is it more likely that Beverly Hills (taking one percent of MET's total deliveries since 1990) or the San Diego Country Water Authority (SDCWA, which takes 26 percent of MET's total) will be able to replace the lost water? Beverly Hills could purchase water from LADWP, build a desalination plant, or even import water 
on trucks. SDCWA, in contrast, could not replace 26 percent of MET's supply very easily. Table 2 (appended) shows large differences in dependency. Dependencies for MET's three largest member agencies (with 54 percent of the votes) vary from 1.00 for SDCWA (high) to 0.68 for MWDOC (Orange County) to 0.29 for LADWP (low).

These findings illuminate the tension between bargaining (votes) and efficiency (water allocation). Because the correlation between votes on the Board of Directors and dependency is 53 percent (for all member agencies), votes on issues affecting dependency (water prices, storage, and imports that are central to MET's mission) are not going to be 100 percent correlated with members' preferences on those issues. Some members will pay for too much reliability while others will get less reliability than they want, and the divergence between dependency and votes ensures that agreement will be difficult to reach. Member agency heterogeneity (preferences) underpins conflict over policies, and policies cannot properly reflect the weighted distribution of these preferences.

To summarize, MET was founded as a cooperative of member agencies with varying characteristics. Initially, these characteristics did not impede cooperative efficiency because MET had abundant and cheap water. But the arrival of the end of abundance (forty to fifty years after MET was founded) meant that members had to choose between reliable water and cheap water. Some members wanted reliable water because they depended on MET for their supplies. Others preferred cheaper water because they had their own supplies. This heterogeneity of preferences meant that political votes at MET would impose policies on all that did not result in the same benefits and costs for all. This situation resulted in conflict in decisionmaking and in decisions that did not suit all.

The biggest problems came from the continued use of institutions for managing water that assumed water was a club good when it had become a common pool good of inadequate supply to meet all demands. The drought of 1977 should have made it clear that MET lacked sufficient water supplies. Instead, it revealed how outdated MET's institutions were. MET needed to cut demand by 10 percent. MET could have used higher prices or preferential rights to cut demand, but imposed usage quotas that penalized agencies that exceeded 90 percent of their recent historical demand. These across-the-board cuts were not just economically inefficient (ignoring both value in use and expected property rights): They created rents for member agencies that were able to insert their preferred wording into the formulas that determined historic use and adjustments for conservation. During the much worse drought of 1987-1991, Los Angeles and SDCWA (San Diego), for example, were paid because their cuts were large relative to the formula. ${ }^{10}$

\section{The cost of conflict within MET}

The end of water abundance revealed many problems with long-standing MET policies and led to disputes over the policies and how to amend them as well as to reforms and other actions members undertook to reduce their exposure. This section describes the costs, most of them too small for the average water customer to notice or too hard to meaningfully quantify. But "under-the-radar" costs are one reason for the persistence of inefficiency. (Additional reasons, and solution approaches to the problem, are explored in a companion article. ${ }^{11}$ )

\section{Costly policies}

Since its foundation, MET's water prices were based on the average cost of delivery, known as "postage stamp pricing" (PSP) because of the way this resembles postage on letters: First class postage costs the same for letters going across town or across the country. Easy to calculate, PSP evenly distributes system costs across all customers (ignoring costs covered by property taxes). The trouble with PSP comes in two forms. First, PSP subsidizes customers that generate a greater share of system costs to the detriment of customers with below-average service costs. MET's giant service area (about 5,300 square miles or nearly 14,000 square kilometers) and differences in population density, water consumption, and infrastructure quality mean that variations in service costs and PSP subsidies can be quite large.

Second, because it is linked to the cost of water service, not the scarcity of the water being delivered, PSP fails to signal scarcity. Average cost pricing encourages more water demand, until a shortage results. But the user-cost of shortage varies-some customers wish to irrigate landscaping, others need water for biotechnology research — and that variation in usage is not reflected in PSP.

MET's member agencies lack a facility for trading water rights, which would be helpful in reducing the cost of shortages. This cost results from the lost opportunity to move water to where it has a higher value (in exchange for money) and thus reduces total social welfare. The Laguna Declaration asserted that trading would never be required because MET would always have plenty of water, but the promise did not last. MET has not recognized this and has done nothing to facilitate trading. Trading could use preferential rights (PRs) or some other system of dividing MET's limited water supplies among member agencies. But MET has never invoked PRs in a shortage (more on this later on), even as PRs provide an obvious method for rationing supplies. The cost of shortage can be reduced with trade; the absence of trade means that the cost of shortage at MET is maximized.

\section{Costly disputes}

Shortages, PSP, and the lack of trading annoyed many of MET's members and they began to lobby for policies that would alleviate their costs: For MET to buy more water or build larger storage facilities, for example. Other members did not want to pay for those costs but did not always get their way. MET's structure as a cooperative with policies and costs that apply to all members implied that policies were debated, 
implemented, and/or tabled based on political grounds, not in terms of economic damage done or willingness to pay. Votes grew more contentious as Los Angeles's subsidies to other members fell and its domination of the Board waned. In 1972, the combined assessed property values, hence Board of Director votes, of the second- and third-largest member agencies (MWDOC and SDCWA) passed that of LADWP (Orange County, San Diego, and Los Angeles, respectively). It can be shown that equality among contestant parties increases the intensity of competition and thus the dissipation of surplus. ${ }^{12}$ For example, persons A, B, and C may vote on how to split A’s US\$3. In voting, A may lose 2:1 to B and C, but the fight before, during, and after voting may cost more than US\$3. At its best, political redistribution does not reduce social welfare (total wealth is still US\$3); but at its worst, redistribution destroys all welfare gains through the cost of conflict. ${ }^{13}$

The scope for conflict increased as MET shifted its revenue base from taxes to sales. The gap between political and economic power widened because votes on MET's board continued to be allocated in proportion to assessed value (the tax base), not to members that bought a larger share of MET's water (the customer base). Thus one can see that LADWP (with many votes but small water purchases) and SDCWA (with fewer votes and large water purchases) might quarrel about decisions that involved spending more money to get more water. The policies that result are inefficient: Researchers have documented the adverse impact of political voting on efficient water management and concluded that a mismatch between voting power and the benefits from trade reduces efficiency. ${ }^{14}$

For examples of contentious votes, one may cite the surprise victory of a MWDOC-coalition over an alliance of LADWP and SDCWA in the choice of MET's new general manager in 2006, lawsuits challenging PSP subsidies, and the decade-long fight over wheeling charges (the price of moving water through MET's distribution system) between SDCWA and other MET members. The wheeling dispute is explored in depth elsewhere. The short version is that SDCWA bought water from farmers outside MET's service area. When SDCWA petitioned to use MET facilities to deliver the water, members voted 25:1 against SDCWA's offer price of US\$97 per acre-foot moved (approximately 326,000 gallons or 1.23 megaliters); the actual cost of delivery was about US\$116 per acre-foot. Instead, members voted to charge SDCWA about US\$250 per acre-foot, which meant that SDCWA was subsidizing them. This dispute went back and forth between 1995 and 2003 before it was ended by a gift of US\$235 million from the State of California to SDCWA. The wheeling dispute left bitter feelings, a hole in the state budget, and the precedent of a high wheeling charge that blocks members from even trying to circumvent MET's monopoly on water imports. (A recent attempt to sell water failed due to uncertainty over access to MET's infrastructure and the cost of wheeling charges. ${ }^{15}$ )

\section{Costly responses}

In a famous book, A.O. Hirschman identified exit, voice, and loyalty as responses to conflict inside an organization. ${ }^{16}$ For most members, MET membership means nominal costs for reasonable benefits, so they are loyal. SDCWA and other members (e.g., the Central Basin MWD and Long Beach) have used voice-protesting MET policies that ignore PRs or subsidize water consumption. For most members, exit is not an option. Although they may have had adequate water supplies when they joined MET, additional supply led to higher demand that made them dependent. They cannot exit MET without serious consequences. That does not keep them from making efforts to lower their vulnerability to political decisions at MET. SDCWA, for example, is spending hundreds of millions of dollars to build desalination, storage, and water treatment facilities that either duplicate MET facilities or add capacity at much higher costs. SDCWA's management justifies these expenditures as “drought proofing,” but they really are "MET-proofing" themselves from the short end of a drought-stick.

In contrast, LADWP used the Los Angeles aqueduct to insulate itself from MET policies. In 2006, for example, LADWP announced it would use the aqueduct to take delivery of water from farmers outside MET's service area. ${ }^{17}$ This move was similar to SDCWA's deal with farmers, but the use of the aqueduct allowed LADWP to avoid the wheeling charges that LADWP voted to levy on SDCWA.

MET has tried to reduce the cost of shortages, PSP, and a lack of water trading in the least efficient, but most familiar, way by building a US\$2 billion reservoir, the Diamond Valley Lake (DVL). DVL and the US\$1.2 billion pipeline connecting DVL to other supply networks will not help much without more supply, but disputes over MET imports from northern California mean that supplies are more likely to fall than to rise. ${ }^{18}$

Perhaps the worst response to shortage and conflict has been the abrogation of preferential rights, meant to compensate LADWP and others for their heavy payments to cover MET's costs and facilitate water rationing in shortage. Instead of being used in the 1977 and the 1987 to 1991 droughts, MET's members voted to ration water according to prior use and formulas for water conservation that reflected political power more than economic efficiency or value. These formulas retard conservation in wet years that would reduce rights in the next drought, favor some members at the expense of others (conservation via low-flush toilets is ok, xeriscaping is not), and wholly fail to allocate water according to value in use (via prices and/or markets). The companion article discusses why these policies persist-inertia, the mismatch between political votes and economic costs, a management culture that favors bureaucracy over efficiency, and that rate payers rather than politicians and bureaucrats suffer the costs of conflict, shortage, and inefficiency - and what solution approaches are available. 


\section{Conclusion}

Even if it does not provide an easy answer of how things can go right, MET provides a useful case study of how things can go wrong. MET's member agencies waste a lot of time and money on conflict over the allocation of water and costs, and to resolve the problem one cannot just say "play nice.” That is because these problems can be traced to the continued use of institutions that were established in an era of abundant water and money, when demand was weak, and subsidies easy. The change in conditions linked to the end of abundance has not led to a change in policies due to a combination of inertia, professional conservatism, weak incentives to reform (costs and benefits accrue to different parties), and a Tragedy of the Anticommons voting structure that makes it easy for any of many different coalitions to block change. ${ }^{19}$

The lessons from this case study apply elsewhere, to organizations whose institutions have failed to evolve in response to changing external conditions, to organizations with multiple objectives (profits and social responsibility, for example), and to organizations that have weak connections between those who govern and those who experience the implications of governance. The lessons do not often apply to profit-seeking organizations because competition force these organizations to change their activities if they want to maintain profits; weak governance is also less of a problem, because shareholders have greater control of the Board of Directors. This is not true at MET, where directors are sometimes directly elected but often appointed by member agencies that provide water to customers without alternative suppliers and very little insight into the connection between their water bill and decisions on wholesale water supply. The lessons also apply to other nonprofit and bureaucratic organizations in which heterogeneous objectives, cross-subsidies, and weak feedback on management decisions make it easy to get sidetracked. Thus, one might see how USAID - the United States' overseas aid agency-may simultaneously market agricultural surpluses, pursue international development, and lobby for U.S. Department of State objectives. And one may see how NATO may be torn between security and nation-building objectives. The problem is not that the world is complicated; the problem is that organizations and people cannot pursue two "highest and best" objectives simultaneously.

The companion article to this case study explores potential changes in MET's method of pricing and allocating water that would improve efficiency (taking scarcity into consideration) while maintaining equity (distributing benefits and costs according to past actions and population weights). The key feature of this reform is that it realigns MET behind one objective-water provision-by using a market mechanism that reconciles member agencies' heterogeneous demands for water and a per capita method to redistribute revenue in excess of costs back to member agencies.
Notes

David Zetland is a senior water economist in the Department of Environmental Economics and Natural Resources at Wageningen University, The Netherlands. He may be reached at dzetland@gmail.com.

\section{See Diamond (2004).}

2. Quote: Pryor (2007, p. 13).

3. Los Angeles had separate organizations for water and power until 1937, when it merged its Bureaux of Power \& Light and Water Works \& Supply into LADWP.

\section{Milliman (1956).}

5. “Annexation” was voluntary; it is MET's term for “joining”: A new member applies; existing members approve the application.

6. For the economic argument, see Hart and Moore (1996; 1998).

7. Zetland (2008a, chapter 5). Preferences range from strictly self-interested (zero weight for the welfare of others in one's utility function) to benevolence to the point of self-sacrifice (overweighting the welfare of others). These preferences do not exactly match the meanings or uses of "egoic" or "benevolent." Those words relate to feelings toward self or others; actions-not feelings-reveal preferences in the utility function.

\section{Lach, et al. (2005).}

9. To find a single measure of each agency's dependency, divide each member's share in each of the two dependencies (MET's share of a member's total water supply, METSh $_{i}$, and the member's share in MET's total sales, ShMET $\mathrm{T}_{\mathrm{i}}$ by the largest share in each dependency (normalizing each dependency measure to fit a 0 to 1 scale), and divide the average of those two values by the largest value of any member agency (again, to fit a 0 to 1 scale). [The exact may be obtained by contacting the author.] The calculations reported in the text use averages from 1970 to 2004 data; results that use 1960 or 1980 starting dates are similar.

\section{Young (1998).}

11. See Zetland (2011). 


\section{Mehlum and Moene (2002).}

13. Utilitarian arguments for redistribution based on the marginal utility of income do not hold here: Water allocation in southern California is not a life or death decision.

\section{Rosen and Sexton (1993).}

15. Lawsuits: Schoch (2008); wheeling dispute: see Zetland (2008a); infrastructure and cost of wheeling charge: GWI Staff (2009).

\section{Hirschman (1970).}

\section{See LADWP (2006).}

18. Serjeant and Woodall (2008); Zetland (2009b).

19. Heller (1998).

\section{References}

Diamond, J. 2004. Collapse: How Societies Choose to Fail or Succeed. New York: Viking Adult.

GWI Staff. 2009. “Chino Basin Auction Postponed as Bidders Take Fright.” Global Water Intelligence. 5 November 2009.

Hart, O. and J. Moore. 1996.” The Governance of Exchanges: Members' Cooperatives versus Outside Ownership.” Oxford Review of Economic Policy. Vol. 12, No. 4, pp. 53-69.

Hart, O. and J. Moore. 1998. “Cooperatives vs. Outside Ownership.” NBER Working Paper 6421.

Heller, M.A. 1998. "The Tragedy of the Anticommons: Property in the Transition from Marx to Markets.” Harvard Law Review. Vol. 111, No. 3, pp. 621-688.

Hirschman, A.O. 1970. Exit, Voice and Loyalty. Cambridge, MA: Harvard University Press.

Lach, D., S. Rayner, and H. Ingram. 2005. "Maintaining the Status Quo: How Institutional Norms and Practices Create Conservative Water Organizations.” Texas Law Review. Vol. 83, No. 7, pp. 2027-2053.

[LADWP] Los Angeles Department of Water and Power. 2006. “LADWP, State Sign Agreement Allowing Water Transfers from California Aqueduct to Los Angeles Aqueduct.” Press Release, Los Angeles Department of Water and Power. 9 June 2006.

Mehlum, H. and K. Moene. 2002. "Battlefields and Marketplaces.” Defence and Peace Economics. Vol. 13, No. 6, pp. 485-496.
Milliman, J.W. 1956. "The History, Organization and Economic Problems of the Metropolitan Water District of Southern California.” PhD Dissertation (economics). Los Angeles, CA: University of California, Los Angeles.

Pryor, F.L. 2007. "Water Stress and Water Wars." The Economics of Peace and Security Journal. Vol. 2, No. 2, pp. 7-18.

Rosen, M.D. and R.J. Sexton. 1993. "Irrigation Districts and Water Markets: An Application of Cooperative Decision-Making Theory.” Land Economics. Vol. 69, No. 1, pp. 39-53.

Schoch, D. 2008. "Southeast L.A. County Water Agency Sues over MWD Drought Plan.” The Los Angeles Times, 18 April 2008.

Serjeant, J. and B. Woodall. 2008. "Tunnels to Bring Water to Parched California.” Reuters. 20 August 2008.

Young, M.B. 1998. "Draft Paper on Events Leading up to and Chronology of the 1990-92 Drought Years and Supply Reliability Improvements Achieved as a Result of the Drought.” Memo to member agency managers, Metropolitan Water District of Southern California. 25 August 1998.

Zetland, D. 2008a. "Conflict and Cooperation Within an Organization: A Case Study of the Metropolitan Water District of Southern California.” PhD Dissertation (agricultural and resource economics). Davis, CA: University of California, Davis.

Zetland, D. 2008b. "Focal Points in Public Goods Games: Explicit Information Increases Reciprocation.” Working Paper, SSRN Working Paper 1122144.

Zetland, D. 2009a. Conflict and Cooperation Within an Organization: A Case Study of the Metropolitan Water District of Southern California. Saarbrücken: VDM Verlag.

Zetland, D. 2009b. "Water Reallocation in California: A Broken Hub Will Not Wheel.” Journal of Contemporary Water Research and Education. Vol. 144, pp. 18-28.

Zetland, D. 2011. "How Markets can End Persistent Intra-Organizational Conflict." The Economics of Peace and Security Journal. Vol. 6, No. 1, pp. 22-27. 
(c) www.epsjournal.org.uk - Vol. 6, No. 1 (2011)

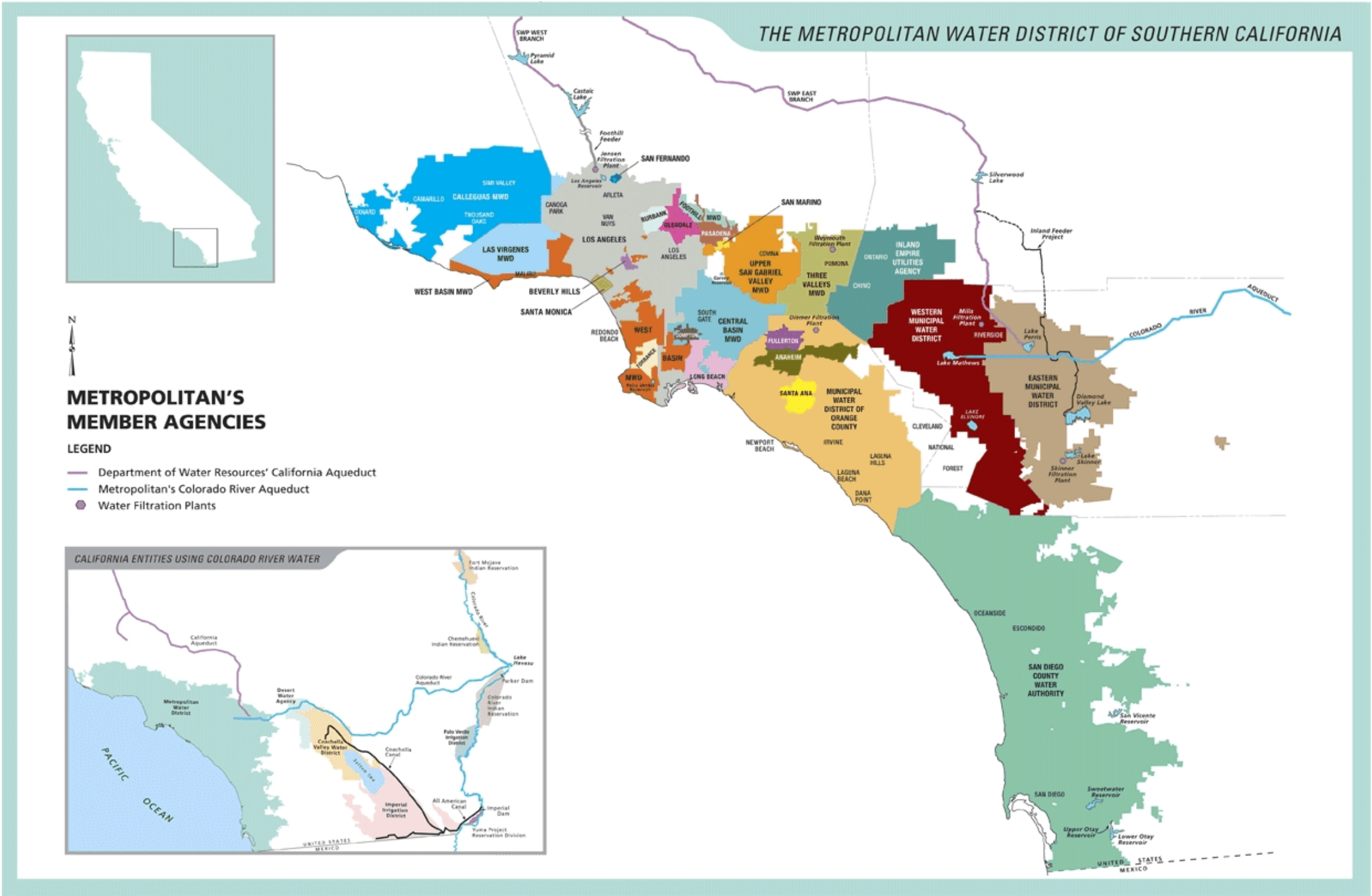

Figure 1: MET's member agencies and service area. Source: MET. 
(C) www.epsjournal.org.uk - Vol. 6, No. 1 (2011)

Table 1: Characteristics of MET's 26 member agencies (2004 to 2006)

\begin{tabular}{|c|c|c|c|c|c|c|c|c|c|}
\hline $\begin{array}{l}\text { Member } \\
\text { agency }\end{array}$ & $\begin{array}{l}\text { Area } \\
\text { (sq. miles) }\end{array}$ & $\begin{array}{l}\text { Population } \\
\left({ }^{\circ} 000 \mathrm{~s}\right)\end{array}$ & $\begin{array}{l}\text { Year } \\
\text { joined }\end{array}$ & $\frac{\text { Board o }}{\text { (seats) }}$ & $\frac{\text { f Directors }}{\text { (\% votes) }}$ & $\begin{array}{l}\text { Share of sales } \\
(1979-2005)\end{array}$ & $\begin{array}{l}\text { Water uses } \\
\text { (\% urban/ag) }\end{array}$ & $\begin{array}{l}\text { Water sources } \\
\text { (\% local/MET) }\end{array}$ & $\begin{array}{l}\text { Preferential } \\
\text { Rights (2005) }\end{array}$ \\
\hline Anaheim & 50 & 340 & 1928 & 1 & 1.7 & 1.3 & $100 / 0$ & $75 / 25$ & 0.93 \\
\hline Beverly Hills & 6 & 41 & 1928 & 1 & 0.9 & 1.7 & $100 / 0$ & $14 / 86$ & 1.01 \\
\hline Burbank & 17 & 105 & 1928 & 1 & 0.9 & 1.0 & $100 / 0$ & $50 / 50$ & 0.95 \\
\hline Calleguas & 395 & 517 & 1960 & 1 & 4.0 & 5.4 & $84 / 16$ & $24 / 76$ & 3.75 \\
\hline Central Basin & 227 & 1,400 & 1954 & 2 & 5.5 & 5.7 & $100 / 0$ & $65 / 35$ & 7.78 \\
\hline Compton & 8 & 93 & 1931 & 1 & 0.2 & 0.2 & $100 / 0$ & $47 / 53$ & 0.26 \\
\hline Eastern & 555 & 105 & 1951 & 1 & 2.8 & 2.9 & $74 / 26$ & $20 / 80$ & 3.00 \\
\hline Foothill & 22 & 80 & 1953 & 1 & 0.6 & 0.6 & $100 / 0$ & $40 / 60$ & 0.68 \\
\hline Fullerton & 22 & 134 & 1931 & 1 & 0.7 & 0.7 & $100 / 0$ & $66 / 34$ & 0.59 \\
\hline Glendale & 31 & 200 & 1928 & 1 & 1.1 & 1.4 & $100 / 0$ & $15 / 85$ & 1.28 \\
\hline Inland Empire & 242 & 700 & 1951 & 1 & 3.8 & 3.0 & $100 / 0$ & $70 / 30$ & 2.43 \\
\hline Las Virgenes & 122 & 65 & 1960 & 1 & 0.9 & 1.0 & $99 / 1$ & $0 / 100$ & 0.77 \\
\hline Long Beach & 50 & 487 & 1931 & 1 & 1.8 & 2.5 & $100 / 0$ & $51 / 49$ & 2.61 \\
\hline Los Angeles (LADWP) & 465 & 3,849 & 1928 & 4 & 19.0 & 10.3 & $100 / 0$ & $70 / 30$ & 21.38 \\
\hline Orange County & 600 & 2,000 & 1951 & 4 & 17.1 & 14.8 & $97 / 3$ & $50 / 50$ & 13.96 \\
\hline Pasadena & 26 & 160 & 1928 & 1 & 0.9 & 1.2 & $100 / 0$ & $40 / 60$ & 1.08 \\
\hline San Fernando & 2 & 24 & 1971 & 1 & 0.1 & 0.0 & $100 / 0$ & $100 / 0$ & 0.10 \\
\hline San Marino & 4 & 13 & 1928 & 1 & 0.2 & 0.0 & $100 / 0$ & $90 / 10$ & 0.21 \\
\hline Santa Ana & 27 & 347 & 1928 & 1 & 1.1 & 0.8 & $100 / 0$ & $66 / 34$ & 0.77 \\
\hline Santa Monica & 8 & 90 & 1928 & 1 & 1.1 & 0.6 & $100 / 0$ & 18/82 & 0.90 \\
\hline SDCWA & 1,457 & 2,840 & 1946 & 4 & 18.3 & 26.6 & $85 / 15$ & $15 / 85$ & 16.16 \\
\hline Three Valleys & 133 & 600 & 1950 & 1 & 2.5 & 3.5 & $100 / 0$ & $40 / 60$ & 2.55 \\
\hline Torrance & 20 & 112 & 1931 & 1 & 1.1 & 1.1 & $100 / 0$ & 8/92 & 1.18 \\
\hline Upr. San Gabriel & 144 & 900 & 1960 & 1 & 3.5 & 2.3 & $100 / 0$ & $20 / 80$ & 3.89 \\
\hline West Basin & 185 & 900 & 1948 & 2 & 6.6 & 8.7 & $100 / 0$ & $20 / 80$ & 8.22 \\
\hline Western & 509 & 600 & 1954 & 1 & 3.6 & 3.7 & $68 / 32$ & $76 / 24$ & 3.56 \\
\hline Totals/averages & 5,327 & 16,702 & $\mathbf{n} / \mathbf{a}$ & 37 & 100 & 100 & $93 / 7$ & $38 / 62$ & 100 \\
\hline
\end{tabular}

Source: Appendix D.1 of Zetland (2008a).

Note: Fourteen cities (highlighted) sell water at retail; the remaining twelve, all MWD's, sell wholesale water to more than 230 water agencies. 
(C) www.epsjournal.org.uk - Vol. 6, No. 1 (2011)

Table 2: The Dependency Index for MET's member agencies depends on MET's share of their total water supply and their share of MET's total sales

\begin{tabular}{|c|c|c|c|}
\hline $\begin{array}{l}\text { Member } \\
\text { agency }\end{array}$ & $\begin{array}{l}\text { MET's share of } \\
\text { MA supply }\end{array}$ & $\begin{array}{l}\text { MA's share of } \\
\text { MET sales }\end{array}$ & $\begin{array}{l}\text { Dependency } \\
\text { index (DI) }\end{array}$ \\
\hline SDCWA & 83 & 26 & 1.00 \\
\hline West Basin & 92 & 11 & 0.73 \\
\hline Orange County & 63 & 16 & 0.68 \\
\hline Beverly Hills & 93 & 1 & 0.55 \\
\hline Las Virgenes & 91 & 1 & 0.54 \\
\hline Calleguas & 75 & 5 & 0.52 \\
\hline Torrance & 80 & 1 & 0.48 \\
\hline Glendale & 76 & 1 & 0.46 \\
\hline Burbank & 73 & 1 & 0.44 \\
\hline Central Basin & 47 & 7 & 0.41 \\
\hline Long Beach & 62 & 3 & 0.41 \\
\hline Santa Monica & 65 & 1 & 0.38 \\
\hline Foothill & 59 & 1 & 0.35 \\
\hline Pasadena & 55 & 1 & 0.34 \\
\hline Three Valleys & 45 & 3 & 0.31 \\
\hline Los Angeles & 23 & 8 & 0.29 \\
\hline Fullerton & 44 & 1 & 0.27 \\
\hline Eastern & 32 & 3 & 0.24 \\
\hline Compton & 40 & $\sim 0$ & 0.23 \\
\hline Anaheim & 34 & 1 & 0.22 \\
\hline Western & 25 & 3 & 0.21 \\
\hline Santa Ana & 33 & 1 & 0.20 \\
\hline Inland Empire & 23 & 2 & 0.18 \\
\hline Upr. San Gabriel & 18 & 2 & 0.14 \\
\hline San Fernando & 10 & $\sim 0$ & 0.06 \\
\hline San Marino & 9 & $\sim 0$ & 0.05 \\
\hline
\end{tabular}

Source: Author's calculations (see Zetland, 2008a).

Note: "MA" is member agency; DI is mean dependency index, using data from 1970-2004; standard deviation is across all of these years. St.dev. has a mean

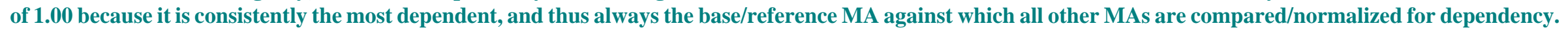

